\title{
Effect of bacterial biofertilizers, native arbuscular mycorrhizal fungi and soil amendments on soil and grain phosphorus availability of flooded rice in dry zone, Sri Lanka
}

\author{
Yapa P.N ${ }^{* 1}$, Sandaruwan, M.K.D.D ${ }^{2}$, Duminda, D.M.S ${ }^{3}$, Bamunuarachchige T.C ${ }^{4}$ \\ ${ }^{1}$ Department of Biological Sciences, Faculty of Applied Sciences, Rajarata University of Sri Lanka, Mihintale \\ ${ }^{2}$ Department of Physical Sciences, Faculty of Applied Sciences, Rajarata University of Sri Lanka, Mihintale \\ ${ }^{3}$ Department of Agricultural Engineering and Soil Science, Faculty of Agriculture, Rajarata University of Sri Lanka, Puliankulama, \\ Anuradhapura \\ ${ }^{4}$ Department of Bioprocess Technology, Faculty of Technology, Rajarata University of Sri Lanka, Mihintale
}

*Email: pnyapa40@yahoo.co.uk, neelamanie@as.rjt.ac.lk

\begin{abstract}
Rice is considered as the most important food crop in Sri Lanka and most of the Asian countries. Over the past three decades, rice farmers have become increasingly dependent on synthetic chemical phosphorous fertilizers, mainly triple super phosphate (TSP) as a source of phosphorous (P). However, dramatically increasing costs, serious environmental and health issues attached to chemical fertilizers, forced researchers to develop supplementary or alternate sources of $\mathrm{P}$ for rice. Hence, this study was done to evaluate the potential use of biofertilizers and natural soil amendments as alternatives to chemical P fertilizers in rice (Oryza sativa L.) farming in the dry zone of Sri Lanka. A field trial was carried out at Ranpathwela in Anuradhapura, North Central Province, Sri Lanka, during the Yala season in 2016. The experiment was designed as follows: CON: control; AMF: AMF inoculants ( $\left.2 \mathrm{Mg} \mathrm{ha}^{-1}\right)$; RAMF: ERP (153.3 $\left.\mathrm{kg} \mathrm{ha}^{-1}\right)$ with the AMF inoculants (2 $\left.\mathrm{Mg} \mathrm{ha}^{-1}\right)$; MC: mixed microbial culture (5 $\left.\mathrm{kg} \mathrm{ha}^{-1}\right)$; RMC: ERP (153.3 $\left.\mathrm{kg} \mathrm{ha}^{-1}\right)$ with a mixed microbial culture [consortium of Azospirillum sp., Pseudomonas sp. and Bacillus sp. (5 L ha $\left.{ }^{-1}\right)$; BC: biochar $\left(6 \mathrm{Mg} \mathrm{ha}^{-1}\right)$; CP: standard compost $\left(10 \mathrm{Mg} \mathrm{ha}^{-1}\right)$ and IF: inorganic synthetic fertilizer (125 $\mathrm{N} \mathrm{kg} \mathrm{ha}{ }^{-1}, 62.5 \mathrm{P}_{2} \mathrm{O}_{5} \mathrm{~kg} \mathrm{ha}^{-1}$ and $50 \mathrm{~K}_{2} \mathrm{O} \mathrm{kg} \mathrm{ha}{ }^{-1}$ ). Three indigenous and two improved rice varieties were used. The experiment comprised of 24 plots and three replicates. Soil, roots and grains of rice were analyzed for phosphorus. Some other elements were shown to have an effect on plant available soil $\mathrm{P}$ such as aluminum and iron, were also estimated. It was revealed that significant differences $(\mathrm{p}<0.05)$ in variety, treatment and $\mathrm{V} \times \mathrm{T}$ interaction was observed in plant available soil phosphorus. The highest mean of available soil P was observed in TRSP2 x AMF $\left(14.64 \pm 0.12 \mathrm{mg} \mathrm{kg}^{-1}\right)$ followed by TRSP3 x MC $(8.87 \pm 0.001$ $\mathrm{mg} \mathrm{kg}^{-1}$ ) interactions. The multifunctional microbial consortium in amended soil, including Azospirillum sp., Pseudomonas sp. Bacillus sp. and arbuscular mycorrhizal fungi, were capable of potentially increasing soil phosphorus. Furthermore, the addition of rock phosphate did not always make a difference in soil $\mathrm{P}$ availability for rice farming systems.
\end{abstract}

Keywords - Triple super phosphates, Eppawala rock phosphate, rice, phosphorus, arbuscular mycorrhizae, phosphorus solubilizing bacteria

\section{INTRODUCTION}

Phosphorus (P) is an essential macronutrient for proper growth and development of plants (Cordell et al., 2009). In tropical regions, plant - available soil $\mathrm{P}$ is often limited (Sharma et al., 2013). The $\mathrm{P}$ level in soil is about $0.05 \%(\mathrm{w} / \mathrm{w})$, and plants can only use up to $0.1 \%$ of this phosphorus (Sharma et al., 2013). Orthophosphate $\mathrm{P}$ ions, usually $\mathrm{H}_{2} \mathrm{PO}_{4}^{-}$and $\mathrm{HPO}_{4}^{-2}$ is present in the soil solution as inorganic phosphorus (Hinsinger, 1998). The soluble inorganic $\mathrm{P}$ for plants absorption is limited because of its fixation with cations forming insoluble phosphates (Sharma et al., 2013). Phosphorus is fixed by cations such as $\mathrm{Ca}^{2+}$ to form a calcium phosphate $\left[\mathrm{Ca}_{3}\left(\mathrm{PO}_{4}\right)_{2}\right]$ complex. Furthermore, with $\mathrm{Al}^{3+}$ and $\mathrm{Fe}^{3+}$ in acidic soils, aluminum phosphate $\left(\mathrm{AlPO}_{4}\right)$ and ferrous phosphate $\left(\mathrm{FePO}_{4}\right)$ are formed respectively (Vassilev et al., 2006; Bünemann et al., 2018). It was reported that around 75$90 \%$ of soil applied chemical phosphate fertilizers are rapidly converted into such metal-cation phosphates and are insoluble, hence difficult to uptake by plant roots (Grant et al.,
2004; Vassilev et al., 2006; Rivaie et al., 2008). Therefore, the regular application of these $\mathrm{P}$ fertilizers is needed and it creates long-term undesirable environment and health impacts (Walpola and Yoon, 2012).

Different phosphorus fertilizers are used by farmers includes, triple super phosphate (TSP), single super phosphate (SSP), ammonium phosphate (AP) and rock phosphate (RP). Triple super phosphate (TSP) is the most common $\mathrm{P}$ fertilizer used in rice farming in the North Central Province (NCP) of Sri Lanka. Generally, TSP is produced with the addition of concentrated phosphoric acid to a ground phosphate rock. Triple super phosphate contains approximately $17-23 \%$ of $\mathrm{P}$ and 44-52\% $\mathrm{P}_{2} \mathrm{O}_{5}$ (Bandara et al., 2008). Triple super phosphate and AP are more soluble than RP (Withers et al., 2005).

Eppawala rock phosphate (ERP) is a locally available natural $P$ resource of igneous origin containing about $28 \%$ to $40 \%$ of 
$\mathrm{P}_{2} \mathrm{O}_{5}$ (Dahanayake, 1988). Rock phosphate can be used as an alternative for imported TSP, after the improvement of water solubility (Pitawala et al., 2003). The rock phosphate was successfully introduced to rice cultivation in acid sulphate soils in Mekong delta, Vietnam mainly because of the high effectivity of rock phosphate addition in acid sulphate conditions (Chien et al., 1990). Furthermore, different microbial processes have been used to improve microbial organic acid production and to solubilize rock phosphate (Sabah et al., 2016).

Rice grown in acidic soils in Sri Lanka ERP could be used as a source of $\mathrm{P}$ due to its increased solubility in acidic soils (Ratnayake et al., 2018). The amounts of $\mathrm{P}$ derived from compost amendments are relatively low (below $10 \mathrm{~g} \mathrm{~kg}^{-1}$ ) (Hargreaves et al., 2008). Pseudomonas spp. Agrobacterium spp. and Bacillus circulans are considered as efficient $\mathrm{P}$ solubilizing bacteria (Bhattacharyya and Jha, 2012). The fungi which could solubilize $\mathrm{P}$ are mainly Alternaria, Aspergillus, Trichoderma, Cephalosporium, Penicillium etc. (Srinivasan et al., 2012; Sharma et al., 2013). Furthermore, organic acids, siderophores, protons, hydroxyl ions and $\mathrm{CO}_{2}$ are produced by $\mathrm{P}$ solubilizing microorganisms (Sharma et al., 2013). These substances can chelate cations or reduce the $\mathrm{pH}$ and release phosphorus by substitution of $\mathrm{H}^{+}$for $\mathrm{Ca}^{+2}$ (Illmer and Schinner, 1995; Goldstein, 2000; Seshachala and Tallapragada, 2012).

Phosphorus solubilizing microorganisms also produce acids such as sulfuric, nitric, and carbonic acids (Kim et al., 1997). However, it has been reported that the efficiency of releasing $P$ from inorganic acids and chelating substances in soil is less than that of the organic acids (Kim et al., 1997). Further, arbuscular mycorrhizal fungi (AMF) effectively extend plant roots, aiding crop $\mathrm{P}$ nutrition by increasing the volume of soil where plants can absorb phosphates (Srinivasan et al., 2012).

Soil organic matter (SOM) is considered a major organic $\mathrm{P}$ source in soil. The soil organic P can be reached to $30-50 \%$ of the total $\mathrm{P}$ and is mainly found as inositol phosphate (Rodríguez and Fraga, 1999). According to Halvorson et al. (1990), organic P solubilization is the continuous dissolution of Ca-P compounds. Arbuscular mycorrhizal hyphae have the potential of increasing the root absorbing surface area (Read and Perez-Moreno, 2003). Considering the necessity of practicing sustainable agricultural practices, the present study was planned to assess the potential of biofertilizers, including AMF and natural soil amendments such as compost, biochar and ERP to replace TSP in rice (Oryza sativa L.) farming in the dry zone of Sri Lanka.

\section{MATERIALS AND METHODOLOGY}

The field trial was carried out at Ranpathwela in Anuradhapura, North Central Province Sri Lanka during the Yala season in 2016 ( $\left.8^{\circ} 23^{\prime} 30.8^{\prime \prime} \mathrm{N}, 80^{\circ} 39^{\prime} 03.2^{\prime \prime} \mathrm{E}\right)$. Mean annual precipitation was around $1750 \mathrm{~mm}$ (Eriyagama et al., 2010), with a dry period from May to September (Jayasena et al., 2011). The mean annual temperature is $30-35{ }^{\circ} \mathrm{C}$. The soil type of the field is reddish brown earths (Alfisols) (Wijesundara et al., 2013).

\section{A. Field plot experimental design}

The experimental field comprised of $2410 \mathrm{~m}$ x $3 \mathrm{~m}$ plots. Plots were prepared as rows and separated by $45 \mathrm{~cm}$ double bunds, minimizing the plant nutrient movement from one plot to the another. Ridges of $45 \mathrm{~cm}$ height and width were also made around the plot. Each plot was divided equally into 5 subplots for 5 different rice varieties. One treatment was applied in all 5 subplots to minimize mixing of added amendments.

The treatments were CON: control (no application of soil amendments and biofertilizers); AMF: AMF inoculants (2 Mg ha-1); RAMF: ERP (153.3 $\mathrm{kg} \mathrm{ha}^{-1}$ ) with AMF inoculants (2 $\left.\mathrm{Mg} \mathrm{ha}^{-1}\right)$; MC: mixed microbial culture (5 kg ha-1); RMC: ERP (153.3 $\left.\mathrm{kg} \mathrm{ha}^{-1}\right)$ with mixed microbial culture [mixed culture of Azospirillum sp., Pseudomonas sp. and Bacillus sp. (5 L ha-1)]; BC: biochar (6 $\left.\mathrm{Mg} \mathrm{ha}^{-1}\right)$; $\mathrm{CP}$ : standard compost $\left(10 \mathrm{Mg} \mathrm{ha}^{-1}\right)$ and IF: inorganic synthetic fertilizer $(125 \mathrm{~N} \mathrm{~kg}$ $\mathrm{ha}^{-1}, 62.5 \mathrm{P}_{2} \mathrm{O}_{5} \mathrm{~kg} \mathrm{ha}^{-1}$ and $50 \mathrm{~K}_{2} \mathrm{O} \mathrm{kg} \mathrm{ha}{ }^{-1}$ ). Five rice varieties and three replicates were used randomly.

\section{B. Preparation of biofertilizers and organic amendments prior to field application}

Arbuscular mycorrhizal fungi inoculums were prepared using trap cultures. Soil with root fragments of herbs were collected from the upper layer $(0-15 \mathrm{~cm})$ of the organically managed rice field in Anuradhapura district and used as an indigenous AMF inoculum. Arbuscular mycorrhizal fungi colonized roots from a trap plant culture was used as a source of native AMF inoculum.

Azospirillum sp. was isolated from the rhizosphere soil of the rice field in Anuradhapura. Nfb semi-solid medium was inoculated with $0.1 \mathrm{ml}$ of soil suspension and was incubated at $37{ }^{\circ} \mathrm{C}$ for 72 hours (Dobereiner, 1992). Isolated colonies were streaked on the plates of malate agar medium containing $0.1 \% \mathrm{NH}_{4} \mathrm{Cl}$ to get pure colonies and stored at $-20{ }^{\circ} \mathrm{C}$ (Rodrignuez-Caceres, 1982). Then the isolated Azospirillum

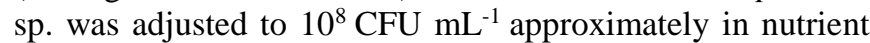
broth (NB) medium and used for Azospirillum inoculum. Pseudomonas fluorescens strains were isolated from the rhizosphere soil, from Anuradhapura and Eppawala rock phosphate deposits in Sri Lanka, following standard procedures using King's B agar medium (KB) (Cody et al., 2008). Potassium solubilizing Bacillus spp. were also isolated by serial dilution method using modified Aleksandrov medium. 


\section{Soil and plant sampling methods for chemical analysis}

Soil samples of $500 \mathrm{~g}$ were collected 2 days prior to harvest from each subplot at a depth of $0-15 \mathrm{~cm}$. Subsamples of soil were collected using a $2 \mathrm{~m}$ x $2 \mathrm{~m}$ sampling grid, excluding the edges in each experimental plot and composite samples were made. Collected soil was air-dried, gently crushed, passed through a $2 \mathrm{~mm}$ sieve and stored for subsequent soil analysis. Rice plant samples were also collected immediately after harvest. Plants were selected from each subplot chosen at random within the $1 \mathrm{~m}^{2}$ field.

\section{Soil pH}

The soil $\mathrm{pH}$ was measured in soil suspension [soil/water ratio of 1:2.5 (w/v)] using the digital $\mathrm{pH}$ meter (Hanna Instruments Inc., USA) (Anderson and Ingram, 1993). Ten grams of soil was transferred into a $50 \mathrm{ml}$ beaker and $25 \mathrm{ml}$ of distilled water was added. After one hour, soil pH was measured regularly by inserting a glass $\mathrm{pH}$-electrode into the saturated soil suspension.

\section{E. Available phosphorus concentration in soil}

Plant available soil $\mathrm{P}$ was measured with $0.5 \mathrm{~mol} \mathrm{~L}^{-1} \mathrm{NaHCO}_{3}$ (pH 8.5) followed by molybdenum blue colorimetric procedure (Olsen et al., 1954; Olsen and Sommers, 1982). For the determination of available soil P, $2.5 \mathrm{~g}$ of sieved soil was measured and transferred into a $250 \mathrm{ml}$ conical flask. Then 50 $\mathrm{ml}$ of $0.5 \mathrm{M}, \mathrm{NaHCO}_{3}$ solution was added to samples and kept on the shaker for 30 minutes under $210 \mathrm{rpm}$. Afterwards 10 $\mathrm{ml}$ of the filtrate was transferred into a $50 \mathrm{ml}$ volumetric flask and $2 \mathrm{ml}$ of $2.75 \mathrm{M}$. $\mathrm{H}_{2} \mathrm{SO}_{4}$ with ammonium vanda-molybdate, the coloring agent was added. Phosphorous content was detected using the Atomic Absorption Spectrophotometer (Model No. UV/1800 APC) under the wavelength of $882 \mathrm{~nm}$.

\section{F. Total phosphorus concentration in rice grains}

Total $\mathrm{P}$ concentrations of rice grains were estimated using the dry-ashing method. For the determination of total $\mathrm{P}$ in a grain sample, $1.0 \mathrm{~g}$ of ground sample was collected in a porcelain crucible and placed in a muffle furnace at $550{ }^{\circ} \mathrm{C}$ temperature for 5 hours and cooled. Afterwards the grain samples were taken out from the furnace and $5 \mathrm{ml}$ of $5 \mathrm{~N} \mathrm{HCl}$ was added and mixed well (Lu, 2000). the grain samples were filtered, coloring reagent was added to the flask and read for $\mathrm{P}$ detection using Atomic Absorption Spectrophotometer (Model No. UV/1800 APC) under $410 \mathrm{~nm}$ wavelength.

\section{G. Plant available soil aluminum and iron}

Soil available concentrations of elements were quantified after being digested by wet acid digesting method and examined for soil available $\mathrm{Al}$ and $\mathrm{Fe}$ contents using Inductively
Coupled Plasma Optical Emission Spectrophotometer (ICPOES) (Thermo Scientific ICAP7400 DUO).

\section{H. Data analysis}

Treatments were arranged in completely randomized design in three replicates. Statistical analyses were performed as two- factor factorial design using the MINITAB statistical software package (MINITAB 17.1.0 version). The two-way ANOVA was applied and the significant differences among the means were tested. The Tukey's test was used to conduct the pairwise comparisons for the significant treatments. The significance level $(\alpha) 0.05$ was used for all the statistical tests. Pearson correlation analysis was done in order to find the correlation among different variables.

\section{RESUlts AND Discussion}

\section{A. Soil pH}

The soil in the experimental plots was slightly acidic before the addition of soil amendments and biofertilizers. Initially, the soil $\mathrm{pH}$ was 6.35 and the increase of the $\mathrm{pH}$ upon submergence of soil was evident. After 100 days of growth of rice, mean soil $\mathrm{pH}$ values changed slightly towards neutral range $(6.46-7.85)$.

Compared to the other rice varieties used, the increase of soil $\mathrm{pH}$ during the rice growth was greater in TRSP2 variety with and without amendments or biofertilizer additions (Fig. 1). It has been reported that the $\mathrm{pH}$ range of soil 6.0 -7.5 is the most productive (Rowell, 1994). The $\mathrm{pH}$ range of all amended soil positively influenced the soil $\mathrm{P}$ availability (Abreu et al., 2005). Furthermore, it was revealed that a significant difference $(\mathrm{p}<0.05)$ was observed among different rice varieties $(\mathrm{V})$, treatments $(\mathrm{T})$ and variety and treatment interactions $(\mathrm{V} \times \mathrm{T})$. The highest mean $\mathrm{pH}$ was observed in TRSP 2 x CON $(7.85 \pm 0.01)$ followed by TRSP 2 x RMC (7.34 $\pm 0.01)$, TRSP $2 \times \mathrm{CP}(7.18 \pm 0.03), \mathrm{TRSP} 2 \times \mathrm{MC}(7.17 \pm 0.06)$ and TRSP2 $x$ RAMF [(7.03 \pm 0.02$)$ Fig. 1]. 




Fig. 1: Mean soil pH with the amended biofertilizers, natural amendments and synthetic fertilizer applications and growth of the different tested rice varieties. Error bars indicate $95 \%$ confidence intervals. Means denoted as same letters do not differ at $\mathrm{p}<0.05$.

(CON: No biofertilizer or amendment addition; AMF: Addition of AMF; RAMF: Rock phosphate + AMF addition; MC: Addition of mixed bacterial culture; RMC: Rock phosphate + mixed microbial culture; BC: Addition of biochar; CP: Addition of compost; IF: Addition of recommended dose of synthetic fertilizer).

Mixed microbial culture (MC and RMC) added treatments showed an increase of $\mathrm{pH}$ with the growth of different rice varieties. Decarboxylation of anionic organic matter by microorganisms could have been increased the $\mathrm{pH}$ (Yan et al., 1996). Nitrogen mineralization by soil microorganisms subsequently produced $\mathrm{OH}^{-}$from organic ligands, also explain the increase of soil pH (Mkhabela and Warnan, 2005). Rock phosphate decreases exchangeable $\mathrm{Al}^{+3}$ in soil resulting an increase in soil $\mathrm{pH}$ to neutral range which enhance the plant available phosphorus (van Der Heide, et al., 1992; Abreu et al., 2005). The soil $\mathrm{pH}$ values of rock phosphate added treatments in this study (RAMF and RMC) were higher compared to the other treatments - for example, in TRSP $2 \mathrm{x}$ $\operatorname{RMC}(7.34 \pm 0.01)$ and TRSP2 $x \operatorname{RAMF}(7.05 \pm 0.02)$.

Soil $\mathrm{pH}$ has been increased in biochar amended subplots (Fig. 1). Biochar increases the cation exchange capacity (CEC), $\mathrm{pH}$ buffering capacity and adsorb $\mathrm{Al}^{+3}$ and $\mathrm{H}^{+}$of the soil (Nigussie et al., 2012). The addition of biochar increases soil $\mathrm{pH}$ was also reported in acidic soil (Zhang et al., 2010; Butnan et al., 2015). According to Mukherjee et al. (2011), combination of soil and biochar may result in different $\mathrm{pH}$ buffering capacities. Soil $\mathrm{pH}$ was increased by $0.11 \%$ for each $\mathrm{Mg} \mathrm{ha}^{-1}$ of biochar applied after 0.5 year of application (Carvalho et al., 2013). Incorporation of biochar into soils was most effective on $\mathrm{P}$ availability, because with the increases of $\mathrm{pH}$ in soil, decreases the $\mathrm{P}$ adsorption onto the $\mathrm{Fe}$ and $\mathrm{Al}$ oxides (Carvalho et al., 2013).

It was also reported that compost increases soil $\mathrm{pH}$, while NPK chemical fertilizer decreases soil pH (Warren Fonteno, 1993; Liu et al., 2010). The decrease of soil $\mathrm{pH}$ by addition of NPK fertilizers could due to leaching of basic cations, such as $\mathrm{Ca}^{+2}, \mathrm{Mg}^{+2}$ while acidic $\mathrm{Al}^{+3}$ ions entering into the soil solution (Whalen et al., 2000). Additionally, nitrification of added $\mathrm{N}$ fertilizer resulted the generation of $\mathrm{H}^{+}$ions leading to soil pH decline (Liu et al., 2010).

\section{B. Plant available phosphorus in soil}

It was revealed that significant differences $(\mathrm{p}<0.05)$ in variety, treatment and $\mathrm{V} \times \mathrm{T}$ interaction was observed in plant available soil phosphorus. The highest mean of available soil $\mathrm{P}$ was observed in TRSP2 $\times$ AMF $\left(14.64 \pm 0.12 \mathrm{mg} \mathrm{kg}^{-1}\right)$ followed by TRSP3 x MC $\left(8.87 \pm 0.001 \mathrm{mg} \mathrm{kg}^{-1}\right)$ TRSP $2 \times$ RMC $\left(6.59 \pm 0.01 \mathrm{mg} \mathrm{kg}^{-1}\right)$ BGSP2 x CON $(6.25 \pm 0.18 \mathrm{mg}$ $\left.\mathrm{kg}^{-1}\right)$ and TRSP2 $\times$ MC [(6.01 $\left.\pm 0.002 \mathrm{mg} \mathrm{kg}^{-1}\right)$ Fig. 2]. It was reported that the optimal range of soil available $\mathrm{P}$ for proper rice growth in Sri Lankan soils is $10-20 \mathrm{mg} \mathrm{kg}{ }^{-1}$ (Kendaragama et al., 2006). The results of the present study revealed that the available $\mathrm{P}$ concentrations were lower than the optimal range of soil available $\mathrm{P}$ in the experimental plots 


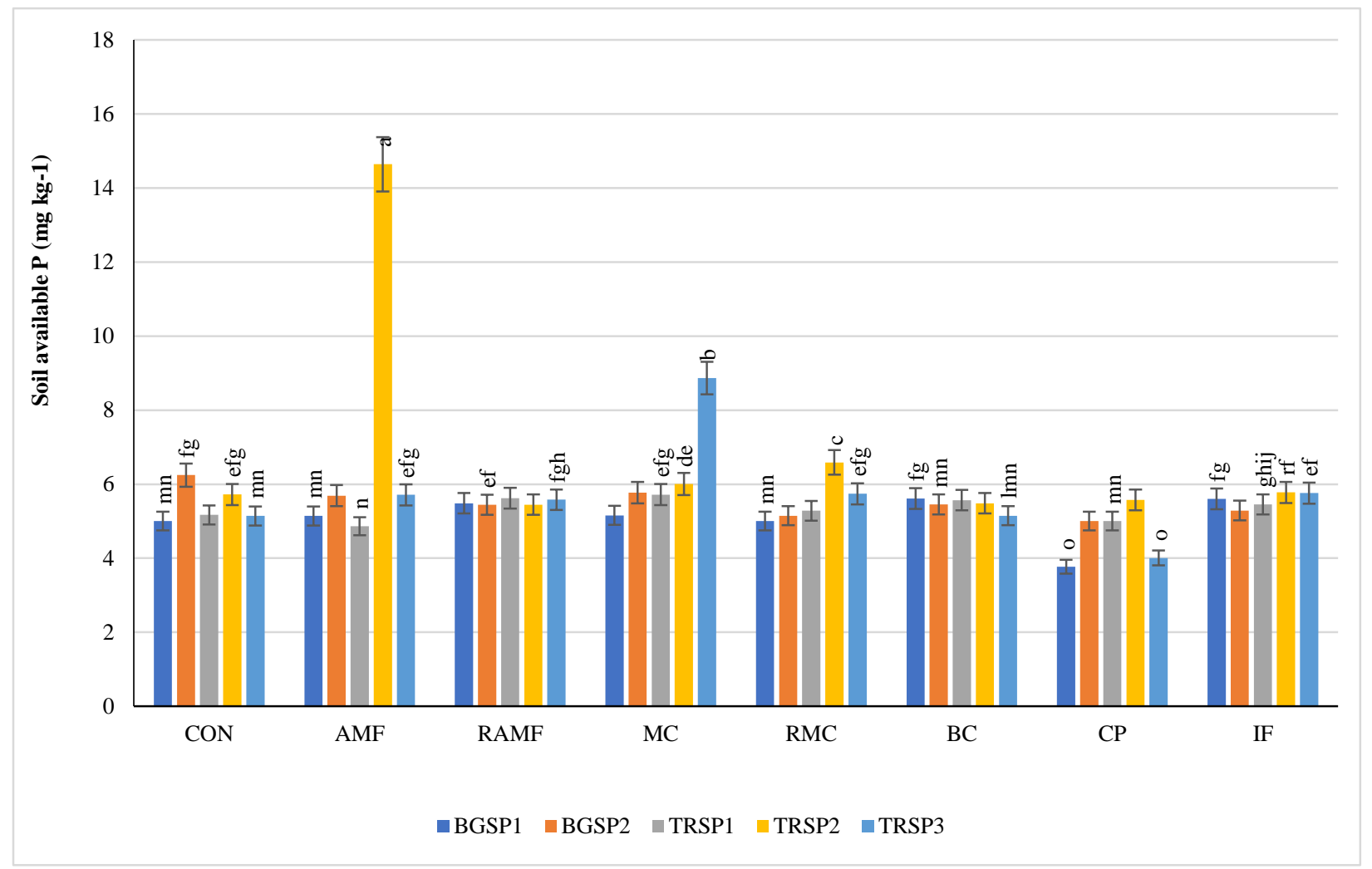

Fig. 2: Mean plant available soil P (mg kg-1) with the amended biofertilizers, natural amendments and synthetic fertilizer applications and growth of the different tested rice varieties. Error bars indicate 95\% confidence intervals. Means denoted as same letters do not differ at $p<0.05$.

CON: No biofertilizer or amendment addition; AMF: Addition of AMF; RAMF: Rock phosphate + AMF addition; MC: Addition of mixed bacterial culture; RMC: Rock phosphate + mixed microbial culture; BC: Addition of biochar; CP: Addition of compost; IF: Addition of recommended dose of synthetic fertilizer).

except TRSP2 x AMF (Fig. 2). However, P deficiency was not observed in any rice plant in any of the treatments. However, Kendaragama et al. (2006), reported that around $44 \%$ of rice growing soils in Sri Lanka, the available soil $\mathrm{P}$ concentration is less than $10 \mathrm{mg} \mathrm{kg}^{-1}$, while the rest have higher $\mathrm{P}$ concentrations, and the mean $\mathrm{P}$ concentration was approximately $13 \mathrm{mg} \mathrm{kg}^{-1}$.

Furthermore, it is estimated that a rice crop with an average yield of $6 \mathrm{Mg} \mathrm{ha}^{-1}$ removes $20 \mathrm{~kg} \quad \mathrm{ha}^{-1} \mathrm{P}$ per season (Amarawansha and Indrarathne, 2010). When a rice plant absorbs $\mathrm{P}$ from the soil, the available soil $\mathrm{P}$ content is reduced (Amarawansha and Indrarathne, 2010). Phosphates fixed by $\mathrm{Fe}^{+2}, \mathrm{Al}^{+3}$ and $\mathrm{Ca}^{+2}$ in soils is a major cause of low soil phytoavailable phosphorus (Pampolino et al., 2018). Approximately $70-90 \%$ of $\mathrm{P}$ in the soil is fixed and hence, not available to be absorbed by plants (Ladha et al., 2003). Biochar and compost showed high affinity for $\mathrm{Al}^{+3}$ and $\mathrm{Fe}^{+2}$ hence, reduce $\mathrm{P}$ fixation. This helps long term chelation of $\mathrm{Al}^{+3}$ and $\mathrm{Fe}^{+2}$ by biochar and compost instead of $\mathrm{P}$ (Major et al., 2010). Then $P$ will become readily available for use by crops and considered as a sustainable strategy to replace conventional $\mathrm{P}$ fertilizers. However, these characteristics could be varied widely with the parent biomass types and production conditions of both biochar and compost (Mukherjee et al., 2011).
Soil bacteria, mainly Pseudomonas and Bacillus, can solubilize organic P by secreting enzymes, which include phosphohydrolases, phytases and phosphonatases (Ladha et al., 2003). Soil P get solubilized by rhizosphere microbial consortium by releasing the phosphatase enzyme, organic acids, and siderophores (Shenoy et al., 2001). Furthermore, organic matter can improve soil $\mathrm{P}$ availability by adsorbing the phosphorus fixing cations (Brady and Weil, 2008). However, the soil $\mathrm{P}$ availability was not substantially increased with the addition of rock phosphate compared to MC and RAMF treatments (Fig. 2).

\section{Plant available aluminum concentration in soil}

Plant available $\mathrm{Al}$ concentration in soil significantly varied $(p<0.05)$ in rice varieties and the interactions (Fig. 3). Among the interactions, the highest available soil $\mathrm{Al}$ concentration was observed in BGSP1 x RAMF $\left(8.68 \pm 0.09 \mathrm{mg} \mathrm{kg}^{-1}\right)$ followed by BGSP2 x CON $\left(8.49 \pm 0.06 \mathrm{mg} \mathrm{kg}^{-1}\right)$, BGSP2 $\mathrm{x}$ CP $\left(7.21 \pm 0.02 \mathrm{mg} \mathrm{kg}^{-1}\right)$, BGSP2 x AMF $\left[\left(6.28 \pm 0.17 \mathrm{mg} \mathrm{kg}^{-}\right.\right.$ $\left.{ }^{1}\right)$ Fig. 3]. Low soil available $\mathrm{Al}$ was observed in IF amended treatment with all 5 rice varieties (Fig. 3). If the soil is acidic and contained high concentration of inorganic $\mathrm{P}$, insoluble Al$\mathrm{P}$ complexes will be formed reducing both available soil $\mathrm{Al}$ and P (Zhang and Matsumoto, 2005). Phosphorous reported 


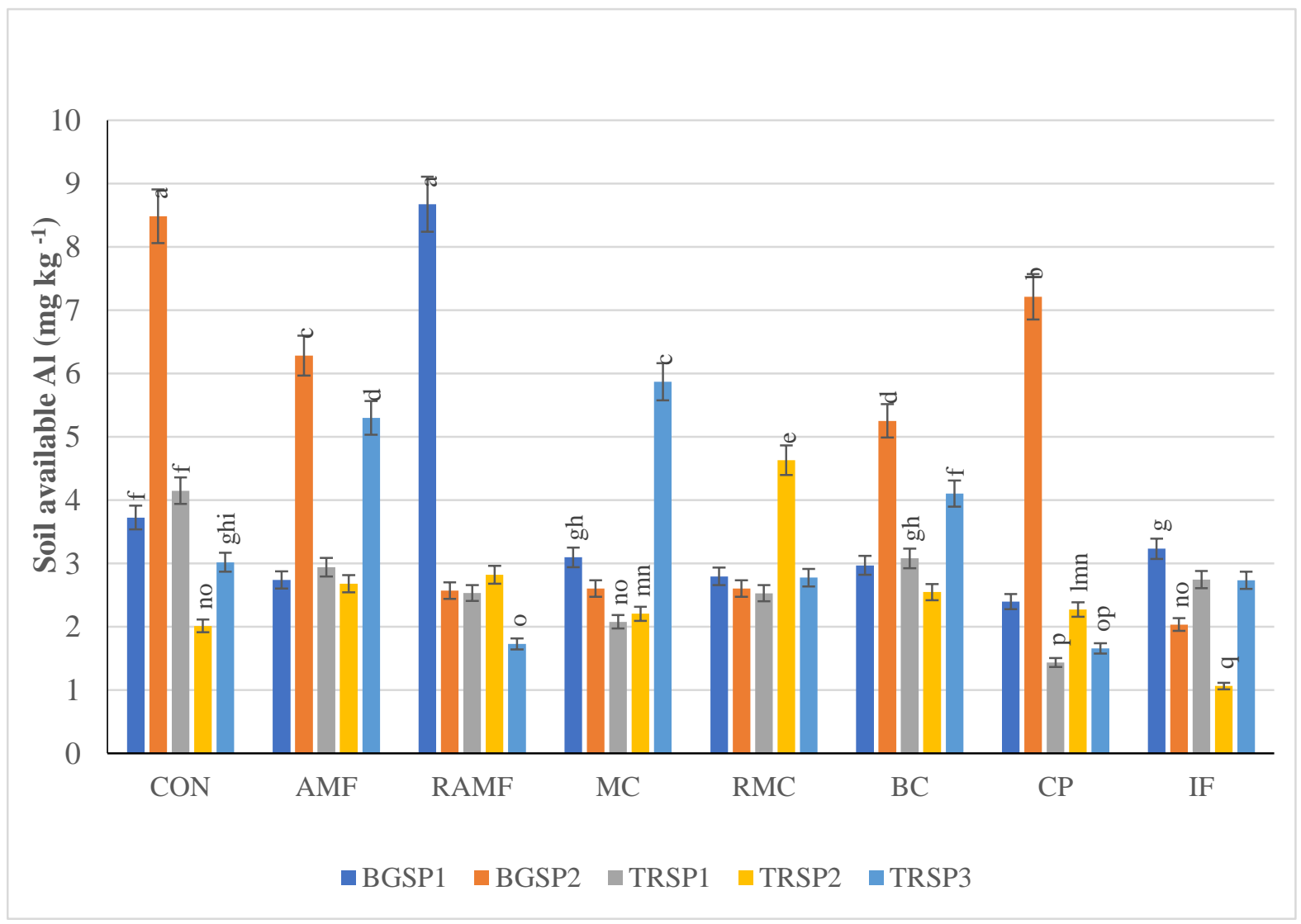

Fig. 3: Mean plant available soil $\mathrm{Al}(\mathrm{mg} \mathrm{kg}-1)$ with the amended biofertilizers, natural amendments and synthetic fertilizer applications and growth of the different tested rice varieties. Error bars indicate $95 \%$ confidence intervals. Means denoted as same letters do not differ at $\mathrm{p}<0.05$.

CON: No biofertilizer or amendment addition; AMF: Addition of AMF; RAMF: Rock phosphate + AMF addition; MC: Addition of mixed bacterial culture; RMC: Rock phosphate + mixed microbial culture; BC: Addition of biochar; CP: Addition of compost; IF: Addition of recommended dose of synthetic fertilizer).

to be alleviated $\mathrm{Al}$ toxicity in plants such as wheat (Iqbal, 2013) and sorghum (Tan and Keltjens, 1990). Soil available $\mathrm{Al}$ concentrations was low in $\mathrm{MC}, \mathrm{RMC}, \mathrm{BC}$ and $\mathrm{CP}$ amended plots except the growth of few rice varieties (Fig. 3). It could be possible that with the amended biochar, soil $\mathrm{pH}$ gets increased and fixed $\mathrm{Al}$ by surface adsorption to the silicates. Therefore, the findings were consistent with Zhang and Matsumoto (2005), that the soil biochar application resulted the $\mathrm{Al}$ adsorption. Humic substances in mature compost also decreases Al concentration in acid soil through forming chelates (Zhang and Matsumoto, 2005). Humic substances in compost also decrease exchangeable $\mathrm{Al}$ through the chelation by functional group, especially carboxylate (Iqbal, 2013).

\section{Plant available iron concentration in soil}

Soil available Fe concentration varied significantly $(\mathrm{p}<0.05)$ with the rice variety, treatment and $\mathrm{V} \times \mathrm{T}$ interactions. The highest soil available Fe was observed in BGSP2 $\mathrm{x}$ IF $(1.38 \pm$ $\left.0.07 \mathrm{mg} \mathrm{kg}^{-1}\right)$ followed by TRSP3 x IF $\left(1.31 \pm 0.08 \mathrm{mg} \mathrm{kg}^{-1}\right)$, TRSP2 x BC $\left(1.24 \pm 0.01 \mathrm{mg} \mathrm{kg}^{-1}\right)$, TRSP $2 \times$ MC $(1.21 \pm 0.01$ $\left.\mathrm{mg} \mathrm{kg}{ }^{-1}\right)$ and BGSP1 $\times$ CP $\left(1.18 \pm 0.01 \mathrm{mg} \mathrm{kg}^{-1}\right)$ respectively (Fig. 4). Soil available $\mathrm{Fe}$ concentrations in organic amendments and biofertilizer added treatments were lower than that of IF treatments (Fig. 4). Iron in the form of oxyhydroxides combines with SOC forming $\mathrm{Fe}$-organic compounds (Lemanceau et al., 2009; Wang et al., 2010). Soil organic matter can effect on different physiochemical reactions that influence the iron availability for plants (Wang et al., 2010). The reduced environmental conditions in flooded rice fields and the addition of compost resulted the increase of $\mathrm{Fe}$ adsorption in complex forms to exchange sites (Lemanceau et al., 2009). Furthermore, build-up of SOC in soil converts adsorbed fractions to more plant accessible forms of $\mathrm{Fe}$ gradually in soil which further increase the plant uptake of micronutrients (Hansch and Mendel, 2009).

Reducing conditions promoting microbial $\mathrm{Fe}^{+3}$ reduction and hence the release of the more mobile $\mathrm{Fe}^{+2}$ from hydrologically connected soils (Grybos et al., 2007). Iron deficiency and an excess in the soil hinder several physiological functions in the rhizosphere and plants (Bashir et al., 2011). Soil microbial activities, such as acidification and secretion of Fe-chelating molecules influence the solubilization and absorption of $\mathrm{Fe}$ in soil (Marschner and Römheld, 1994). Furthrhe release of protons $\left(\mathrm{H}^{+}\right)$in the rhizosphere via $\mathrm{H}^{+}$- ATPase and phytosiderophore secretion in the root zone, increases the availability of Fe in soil (Nozoye et al., 2007). 


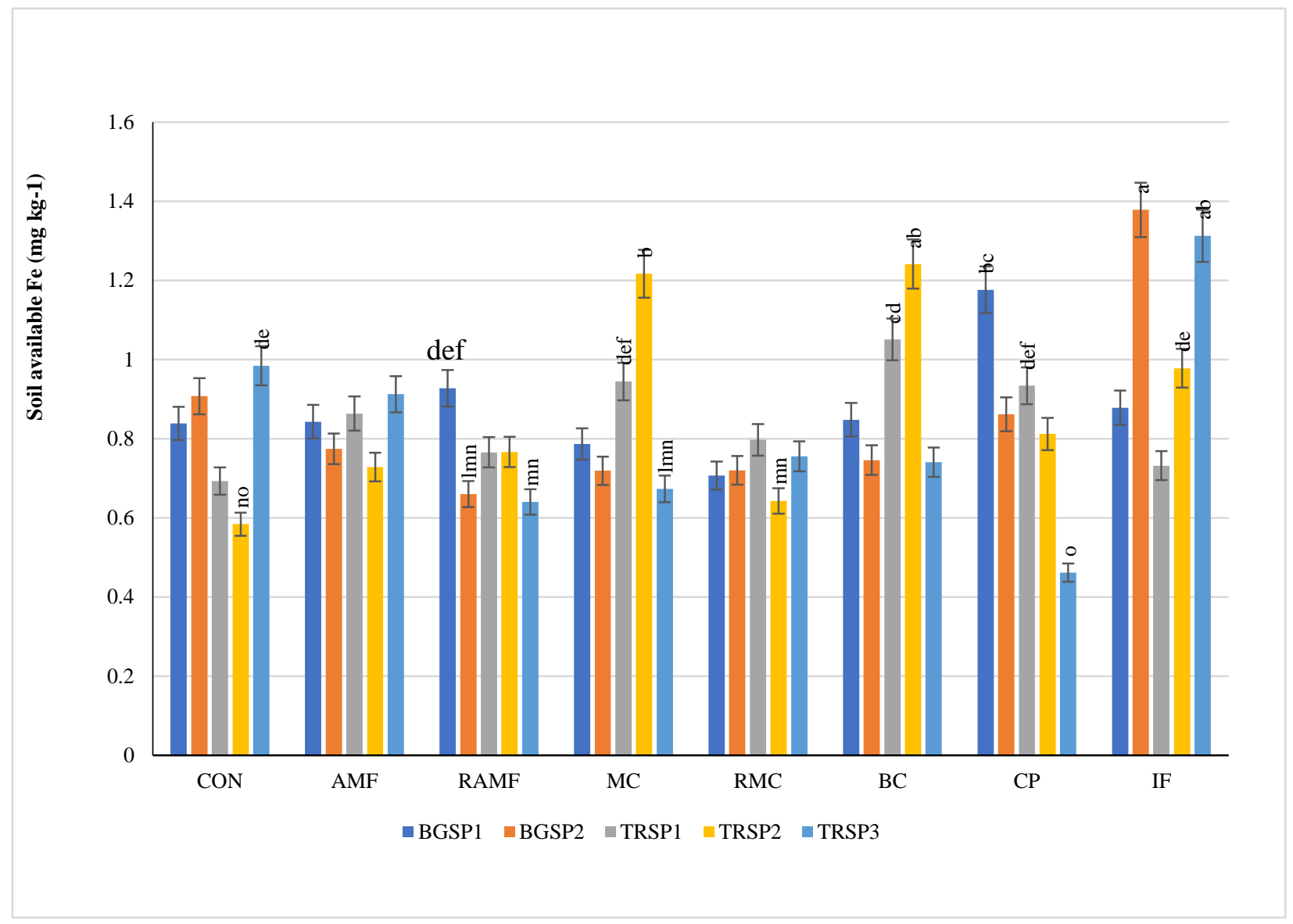

Fig. 4: Mean plant available soil Fe (mg kg-1) with the amended biofertilizers, natural amendments and synthetic fertilizer applications and growth of the different tested rice varieties. Error bars indicate 95\% confidence intervals. Means denoted as same letters do not differ at $\mathrm{p}<0.05$.

CON: No biofertilizer or amendment addition; AMF: Addition of AMF; RAMF: Rock phosphate + AMF addition; MC: Addition of mixed bacterial culture; RMC: Rock phosphate + mixed microbial culture; BC: Addition of biochar; CP: Addition of compost; IF: Addition of recommended dose of synthetic fertilizer).

\section{E. Total phosphorus in rice roots}

Statistical analysis revealed that total root $\mathrm{P}$ content showed significantly different $(\mathrm{p}<0.05)$ with the rice variety, treatment and $\mathrm{V} \times \mathrm{T}$ interactions. The highest level of root $\mathrm{P}$ was observed in BGSP2 $\mathrm{x} \operatorname{RMC}\left(8.73 \pm 0.01 \mathrm{mg} \mathrm{kg} \mathrm{kg}^{-1}\right)$

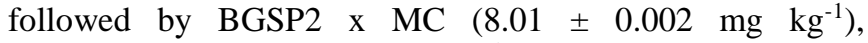
TRSP1x IF $\left(7.01 \pm 0.002 \mathrm{mg} \mathrm{kg}^{-1}\right)$, TRSP2 x MC [(6.87 \pm $0.003 \mathrm{mg} \mathrm{kg}^{-1}$ ) Fig. 5]. Furthermore, IF added treatment plots with different rice varieties were ranged from $4.73 \pm 0.006 \mathrm{mg}$ $\mathrm{kg}^{-1}$ to $7.01 \pm 0.002 \mathrm{mg} \mathrm{kg}^{-1}$ of the TRSP1 $\mathrm{x}$ IF and TRSP2 $\mathrm{x}$ IF interactions respectively (Fig. 5). Arbuscular mycorrhizal fungi have the capability to boost the uptake and root compartmentalization of phosphate (Krishna and Bagyaraj, 1982). However, this phenomenon was not clearly showed in all rice varieties in the present study, because of the submerged conditions for rice growth.
Statistical analysis revealed that the total $\mathrm{P}$ concentration of rice grains were significantly different $(p<0.05)$ in rice variety, treatment and $\mathrm{V} \times \mathrm{T}$ interactions. Among the interactions, the highest $\mathrm{P}$ concentration of rice grain was recorded in RMC x TRSP1 $\left(10.00 \pm 0.91 \mathrm{mg} \mathrm{kg}^{-1}\right)$ followed by BGSP1 x CP $\left(9.29 \pm 0.02 \mathrm{mg} \mathrm{kg}^{-1}\right)$, BGSP1x IF $(8.35 \pm 0.05$ $\left.\mathrm{mg} \mathrm{kg}^{-1}\right), \mathrm{BGSP} 2 \times \mathrm{MC}\left(7.69 \pm 0.4 \mathrm{mg} \mathrm{kg}^{-1}\right), \mathrm{BGSP} 2 \times \mathrm{IF}(7.53$ $\left.\pm 0.06 \mathrm{mg} \mathrm{kg}^{-1}\right)$ and TRSP1 $\mathrm{x}$ MC [(7.47 $\left.\pm 0.05 \mathrm{mg} \mathrm{kg}^{-1}\right)$ Fig. 6]. Phosphorus is accumulated into rice grains after 6 to 15 days of flowering (Allen and Mallarino, 2006). It was estimated that approximately $80 \%$ of the applied $\mathrm{P}$ fertilizer in the world is removed from fields at harvest, mostly in the grains of cereals (Wei et al., 2018). Furthermore, at maturity, $\mathrm{P}$ is mainly accumulated in grains in the form of phytic acid, an that cannot be digested by humans and other monogastric animals (Wei et al., 2018). This could be the reason of finding higher amounts of $\mathrm{P}$ in sewage which affect negatively on water quality and environment (Wei et al., 2018).

\section{F. Total phosphorus in rice grains}




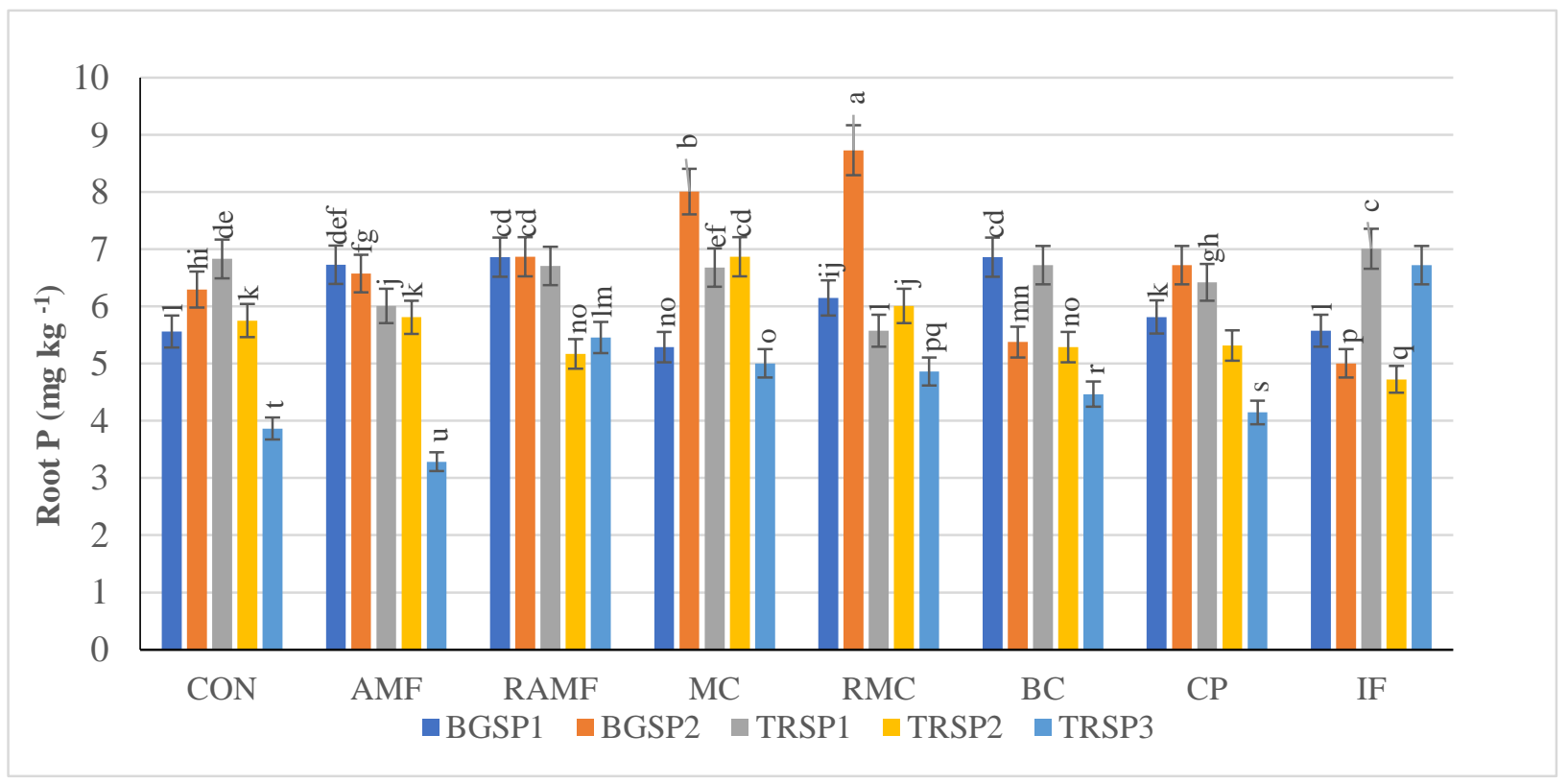

Fig. 5: Mean root total P (mg kg-1) the amended biofertilizers, natural amendments and synthetic fertilizer applications and growth of the different tested rice varieties. Error bars indicate $95 \%$ confidence intervals. Means denoted as same letters do not differ at $\mathrm{p}<0.05$.

CON: No biofertilizer or amendment addition; AMF: Addition of AMF; RAMF: Rock phosphate + AMF addition; MC: Addition of mixed bacterial culture; RMC: Rock phosphate + mixed microbial culture; BC: Addition of biochar; CP: Addition of compost; IF: Addition of recommended dose of synthetic fertilizer).

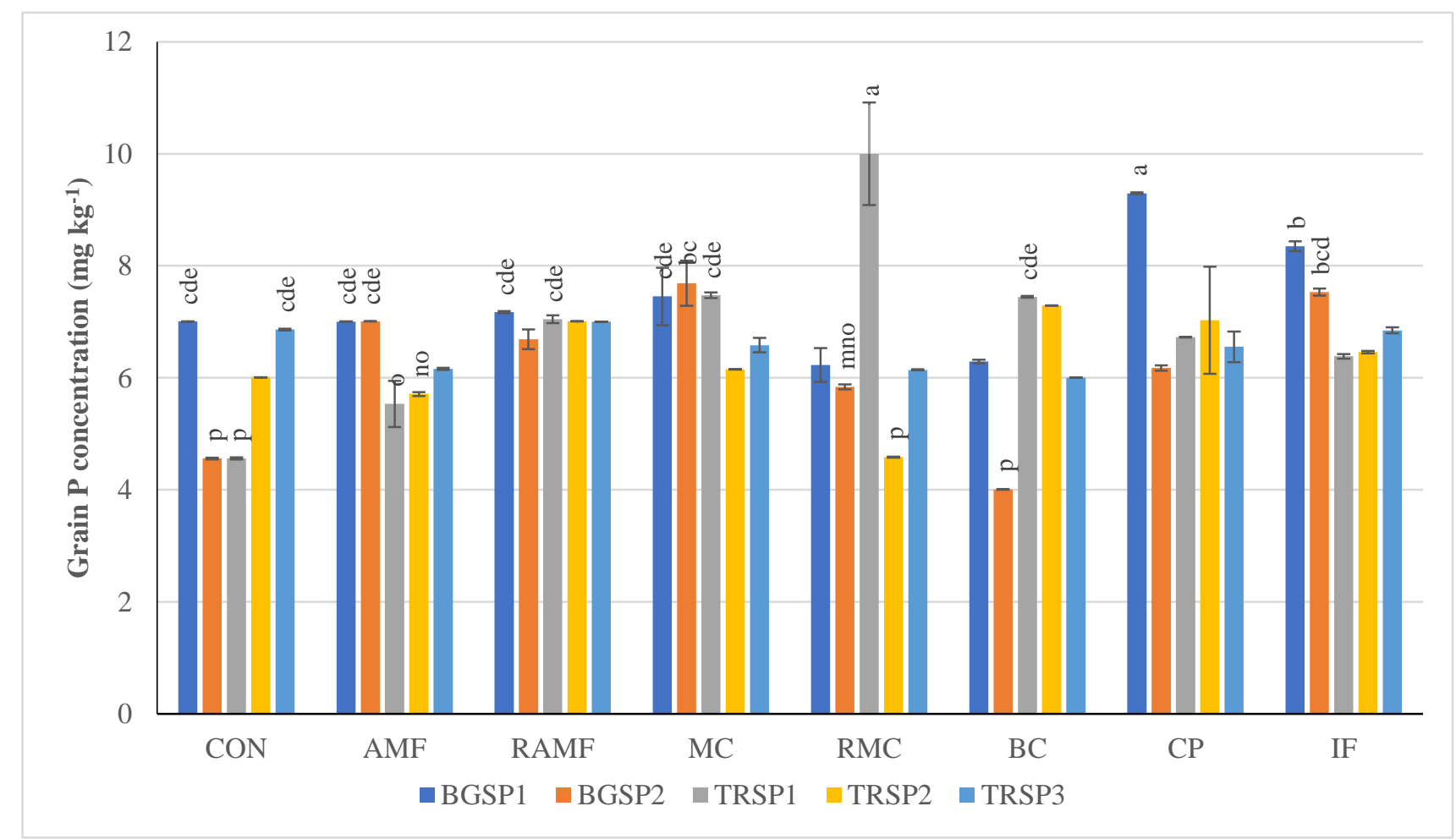

Fig. 6: Mean grain total P (mg kg-1) the amended biofertilizers, natural amendments and synthetic fertilizer applications and growth of the different tested rice varieties. Error bars indicate $95 \%$ confidence intervals. Means denoted as same letters do not differ at $\mathrm{p}<0.05$.

CON: No biofertilizer or amendment addition; AMF: Addition of AMF; RAMF: Rock phosphate + AMF addition; MC: Addition of mixed bacterial culture; RMC: Rock phosphate + mixed microbial culture; BC: Addition of biochar; CP: Addition of compost; IF: Addition of recommended dose of synthetic fertilizer). 


\section{CONCLUSION}

The multifunctional microbial consortium in amended soil, include Azospirillum sp., Pseudomonas sp. Bacillus sp. and arbuscular mycorrhizal fungi, capable of potentially increasing soil $P$. Furthermore, the addition of rock phosphate does not always make a difference in $\mathrm{P}$ availability in the soil for rice plants. However, rice soil management using biofertilizers, organic and synthetic fertilizers still do not have enough $\mathrm{P}$ when compared with ideal soil conditions in fields. Although not considered in this study, monitoring microbial cells and activity during the production and formulation of inoculants and identification of the most efficient microbes which influence on the supply of $\mathrm{P}$ is important to produce more effective biofertilizers for the rice farming in dry zone, Sri Lanka.

\section{REFERENCES}

C.A. Abreu, R. Bvan, M.F. Abreu, A.P. González (2005). Routine soil testing to monitor heavy metals and boron in soils. Scientia Agricola 62: 564-571.

B.L. Allen, A.P. Mallarino (2006). Relationship between extractable soil phosphorus and phosphorus saturation after long-term fertilizer and manure application. Soil Science Society of America Journal, 70: 454 - 463.

E.A.G.S. Amarawansha, S.P. Indrarathne (2010). Degree of phosphorus saturation in intensively cultivated soils in Sri Lanka. Tropical Agricultural Research, 22: 113-119.

J.M. Anderson, J.S.I. Ingram (1993). Tropical soil biology and fertility. A handbook of Methods, C.A.B. International, Wallingtonford, Oxon, UK.

J.M.R.S. Bandara, D.A.M.N. Senevirathna, D.M.R.S.B. Dasanayake, V. Herath, J.M.R.P. Bandara, T. Abeysekara, K.H. Rajapaksha (2008). Chronic renal failure among farm families in cascade irrigation systems in Sri Lanka associated with elevated dietary cadmium levels in rice and freshwater fish (Tilapia). Environmental Geochemistry and Health, 30(5): 465-478.

K. Bashir, Y. Ishimaru, N.K. Nishizawa (2011). Identification and characterization of the major mitochondrial Fe transporter in rice. Plant Signal and Behavior, 6 (10):1591-1593.

P.N. Bhattacharyya, D. K. Jha (2012). Plant growthpromoting rhizobacteria (PGPR): emergence in agriculture. World Journal of Microbiology and Biotechnology, 28:13271350 .

N.C. Brady, R.R. Weil (2008). Soil Colloids: Seat of Soil Chemical and Physical Acidity. In: The Nature and Properties of Soils; Brady, N.C., Weil, R.R., Eds.; Pearson Education Inc.: Upper Saddle River, NJ, USA. pp. 311-358.
E.K. Bünemann, G. Bongiorno, Z. Bai, R.E. Creamer, G.D. Deyn, R. Goede, L. Fleskens, V. Geissen, T.W. Kuyper, P. Mäder, M. Pulleman, W. Sukkelvan, J.W. Groenigen, L. Brussaard (2018). Soil quality - A critical review. Soil Biology and Biochemistry, 120: 105-125.

S. Butnan, J.L. Deenik, B. Toomsan, M.J. Antal, P. Vityakon (2015). Biochar characteristics and application rates affecting corn growth and properties of soils contrasting in texture and mineralogy. Geoderma, 237-238: 105-116.

M. T. M. Carvalho, B. E. Madari, L. Bastiaans, P. A. J. van Oort, A. B. Heinemann, F. da Cassan, M. Diaz-Zorita (2016). Azospirillum sp. in current agriculture: From the laboratory to the field. Soil Biology and Biochemistry 103: 117-130.

S.H. Chien, P.W.G. Sale, D.K. Friesen (1990). A discussion of the methods for comparing the relative effectiveness of phosphate fertilizers varying in solubility. Fertilizer Research 24 (3): 149-157.

W.L Cody, J.W. Wilson, D.R. Hendrixson, K.S. McIver, K.E. Hagman, C.M. Ott, C.A. Nickerson, M.J. Schurr (2008). Skim milk enhances the preservation of thawed -80 degrees $\mathrm{C}$ bacterial stocks. Journal of Microbiological Methods, 75(1): 135-138.

D. Cordell, J.O. Drangert, S. White (2009). The story of phosphorus: Global food security and food for thought. Global Environmental Change, 19: 292-305.

J. Dobereiner (1992). The genera Azospirillum and Herbaspirillum. In: The Prokaryotes ( $2^{\text {nd }}$ ed.): A handbook on the biology of bacteria: ecophysiology, isolation, identification, applications, Blows, A., Truper, H.G., Dworkin, M., Harder, W., Schleifer, K.H. (ed.), Vol. 3, Springer-verlag, New York Inc, pp. 2236-2253.

N. Eriyagama, V. Smakhtin. L. Chandrapala, K. Fernando (2010). Impacts of climate change on water resources and agriculture in Sri Lanka: A review and Preliminary vulnerability mapping; IWMI: Colombo, Sri Lanka. ISBN 978-92-9090-727-5

A. H. Goldstein (2000). Bioprocessing of rock phosphate ore: essential technical considerations for the development of a successful commercial technology, In: Proceedings of the 4th International Fertilizer Association Technical Conference, (Paris: IFA), p. 220.

C.A. Grant, S. Bittman, M. Montreal, C. Plenchette, M. Morel (2004). Soil and fertilizer phosphorus: Effects on plant P supply and mycorrhizal development. Canadian Journal of Plant Science, 24: 163-171. 
M. Grybos, M. Davranche, G. Gruau, P. Petitjean (2007). Is trace metal release in wetland soils controlled by organic matter mobility or Fe-oxyhydroxides reduction? Journal Colloid Interface Science, 314: 490-501.

R. Hänsch, R.R. Mendel (2009). Physiological functions of mineral micronutrients $(\mathrm{Cu}, \mathrm{Zn}, \mathrm{Mn}, \mathrm{Fe}, \mathrm{Ni}, \mathrm{Mo}, \mathrm{B}$, Cl). Current Opinion in Plant Biology, 12 (3): 259-266.

J.C. Hargreaves, M.S. Adl, P.R. Warman (2008). A review of the use of composted municipal solid waste in agriculture. Agriculture Ecosystems and Environment, 123: 1-14.

P. Hinsinger (1998). How do plant roots acquire mineral nutrients? Chemical processes involved in the rhizosphere. Advances in Agronomy, 64: 225-265.

P. Illmer, F. Schinner, (1995). Solubilization of inorganic calcium phosphates-solubilization mechanisms. Soil Biology and Biochemistry, 27: 257-263.

M. Iqbal (2013). Phosphorus enhances aluminum tolerance in both aluminum-tolerant and aluminum-sensitive wheat seedlings. South African Journal Plant and Soil, 30(1): 13-21.

K.M.A. Kendaragama (2006). Crop growing environment in Sri Lanka with special emphasis on plant nutrient use. Journal of Soil Science Society of Sri Lanka, 18: 1-18.

K.Y. Kim, G.A. McDonald, D. Jordan (1997). Solubilization of hydroxyapatite by Enterobacter agglomerans and cloned Escherichia coli in culture medium. Biology and Fertility of Soils, 24: 347-352.

K.R. Krishna, D.J. Bagyaraj (1982). Effect of vesicular arbuscular mycorrhiza and soluble phosphate on Abelmoscus esculentus (L.) Moench. Plant and soil, 64(2): 209-213.

J.K. Ladha, D. Dawe, H. Pathak, A.T. Padre, R.L. Yadav, B. Singh, Y. Singh, P. Singh, A.L. Kundu, R. Sakal (2003). How extensive are yield declines in long-term rice-wheat experiments in Asia? Field Crops Research, 81(2-3): 159-180.

P. Lemanceau, P. Bauer, S. Kraemer, J.F. Briat (2009). Iron dynamics in the rhizosphere as a case study for analyzing interactions between soils, plants and microbes. Plant Soil, 321(1-2): 513-535.

E. Liu, C. Yan, X. Mei, W. He, S.H. Bing, L. Ding, Q. Liu, S. Liu, T. Fan (2010). Long-term effect of chemical fertilizer, straw, and manure on soil chemical and biological properties in northwest China. Geoderma, 158(3): 173-180.
J. Major, M. Rondon, D. Molina, S. Riha, J. Lehmann (2010). Maize yield and nutrition during 4 years after biochar application to a Colombian savanna oxisol. Plant and Soil, 333(1-2): 117-128.

H. Marschner, V. Römheld (1994). Strategies of plants for acquisition of iron. Plant and Soil, 165(2): 261-274.

M. S. Mkhabela, P.R. Warman (2005). The influence of municipal solid waste compost on yield, soil phosphorus availability and uptake by two vegetable crops grown in a Pugwash sandy loam soil in Nova Scotia. Agriculture, Ecosystem and Environment, 106: 57-67.

A. Mukherjee, A.R. Zimmerman, W.G. Harris (2011). Surface chemistry variations among a series of laboratory-produced biochars. Geoderma, 163: 247-255.

A. Nigussie, E. Kissi, M. Misaganaw, G. Ambaw (2012). Effects of biochar application on soil properties and nutrient uptake of lettuces (Lactuca sativa) grown in polluted soils. American-Eurasian Journal of Agriculture and Environmental Science, 12 (3): 369-376.

T. Nozoye, H. Inoue, M. Takahashi, Y. Ishimaru, H. Nakanishi, S. Mori, N.K. Nishizawa (2007). The expression of iron homeostasis-related genes during rice germination. Plant Molecular Biology 64 (1): 35-47.

S.R. Olsen, C.V. Cole, F.S. Watanabe, L.A. Dean (1954). Estimation of available phosphorus in soils by extraction with sodium bicarbonate. US Department of Agriculture Circular 939: 19.

S.R. Olsen, L.E. Sommers, (1982). Phosphorus. In: A.L. Page, R.H. Miller, and D.R. Keeney, editors, Methods of soil analysis. Part 2. Chemical and microbiological properties. 2nd ed. Agronomy Monograph 9(2). ASA and SSSA, Madison, WI. p. 403-430.

M.F. Pampolino, E.V. Laureles, H.C. Gines, R.J. Buresh (2008). Soil carbon and nitrogen changes in long-term continuous lowland rice cropping. Soil Science Society of America Journal, 72: 798- 807.

A. Pitawala, M. Schidlowski, K. Dahanayake, W. Hofmeister (2003). Geochemical and petrological characteristics of Eppawala phosphate deposits, Sri Lanka. Mineralium Deposita, 38(4): 505-515.

U.A.J. Ratnayake, K.D.N. Weerasinghe, U.W.A. Vitharana, K.K.J. Chandika (2018). Potential of Eppawala rock phosphate as a phosphorus fertilizer for rice cultivation in acid sulphate soils in Matara District of Sri Lanka. Tropical Agricultural Research, 29 (4): 293-299. 
A.A. Rivaie, P. Loganathan, J.D. Graham, R.W. Tillman, T.W. Payn, (2008). Effect of phosphate rock and triple superphosphate on soil phosphorus fractions and their plantavailability and downward movement in two volcanic ash soils under Pinus radiata plantations in New Zealand. Nutrient Cycling in Agroecosystems, 82(1): 75-88.

T.L. Roberts (2014). Cadmium and phosphorous fertilizers: the issues and the science. Procedia Engineering, 83: 52-59.

E. A. Rodriguez-Caceres (1982). Improved medium for isolation of Azospirillum spp. Applied and Environmental Microbiology, 44 (4): 990-991.

Rowell, (1994). Soil science: methods and applications. Department of Soil Science, University of Reading. Longman Group, UK. pp. 350.

D. Rowell (1994). Soil science: methods and applications. Department of Soil Science, University of Reading. Longman Group, UK. pp. 350.

N.U. Sabah, G. Sarwar, M.A. Tahir (2016). Comparative efficiency of high (triple super phosphate) and low (rock phosphate) grade $\mathrm{p}$ nutrition source enriched with organic amendment in maize crop. Pakistan Journal of Botany, 48 (6): 2243-2248.

U. Seshachala, P. Tallapragada (2012). Phosphate solubilizers from the rhizosphere of Piper nigrum L. in Karnataka, India. Chilean Journal of Agricultural Research, 72: 397-403.

S.B. Sharma, R.Z. Sayyed, M.H. Trivedi, T.A. Gobi (2013). Phosphate solubilizing microbes: sustainable approach for managing phosphorus deficiency in agricultural soils. Springer Plus, 2 (587): 1-12.

S. K. Shenoy, P.H. McDonald, T.A. Kohout, R.J. Lefkowitz (2001). Regulation of receptor fate by ubiquitination of activated $\beta 2$-adrenergic receptor and $\beta$ arrestin. Science, 294(5545): 1307-1313.

M. Srinivasan, R. Ashwin, D.J. Bagyaraj (2012). Symbiotic response of amla (Emblica officinalis Gaertn.) to different arbuscular mycorrhizal fungi. Journal of Soil Biology and Ecology, 32: 37-44.

K. Tan, W.G. Keltjens (1990). Interaction between aluminum and phosphorus in Sorghum plants. Plant and Soil, 124 (1): 15-23.

J. van Der Heide, J., Setijono, S., Syekhfani, M.S., Flach, E.N., Hairiah, K., Ismunandar, S., Sitompul, S.M., van Noordwijk, M. (1992). Can low external input and cropping system on acid upland soils in the humid tropics be sustainable? AGRIVITA, 15: 1-9.

N. Vassilev, A. Medina, R. Azcon, M. Vassilev (2006). Microbial solubilization of rock phosphate on media containing agro-industrial wastes and effect of the resulting products on plant growth and P uptake. Plant and Soil, 287 (12): $77-84$.

B.C. Walpola, M.H. Yoon (2012). Prospectus of phosphate solubilizing microorganisms and phosphorus availability in agricultural soils: A review. African Journal of Microbiology Research, 6 (37): 6600-6605.

Y.C. Wang, E.L. Wang, D.L. Wang, S.M. Huang, Y.B. Ma (2010). Crop productivity and nutrient use efficiency as affected by long-term fertilization in North China Plain. Nutrient Cycling in Agroecosystems, 86: 105-119.

S. L. Warren, W.C. Fonteno (1993). Changes in physical and chemical properties of a loamy sand soil when amended with composted poultry litter. Journal of Environmental Horticulture, 11: 186-190.

K. Wei, T. Sun, J. Tian, Z. Chen, L. Chen (2018). Soil microbial biomass, phosphatase and their relationships with phosphorus turnover under mixed inorganic and organic nitrogen addition in a Larix gmelinii plantation. Forest Ecology and Management, 422: 313-322.

K. Wei, T. Sun, J. Tian, Z. Chen, L. Chen (2018). Soil microbial biomass, phosphatase and their relationships with phosphorus turnover under mixed inorganic and organic nitrogen addition in a Larix gmelinii plantation. Forest Ecology and Management, 422: 313-322.

J. K. Whalen, C. Chang, G.W. Clayton, J.P. Carefoot (2000). Cattle manure amendments can increase the $\mathrm{pH}$ of acid soils. Soil Science Society of America Journal, 64(3): 962-966.

W.M.G.D. Wijesundara, K.A. Nandasena, A.N. Jayakody (2013). Seasonal and spatial variations of N, P, K and Cd concentrations in water of the Mahakanumulla cascade in the dry zone of Sri Lanka. Tropical Agricultural Research, 24 (3): 279-288.

P.J. Withers, D.M. Nash, C.A. Laboski (2005). Environmental management of phosphorus fertilizers. Phosphorus: Agriculture and the Environment, 46: 781-827.

F. Yan, S. Schubert, K. Mengel (1996). Soil pH increase due to biological decarboxylation of organic anions. Soil Biology and Biochemistry, 28: 617-624. 
H. Zhang, X. Feng, T. Larssen, L. Shang, P. Li (2010). Bioaccumulation of methyl mercury versus inorganic mercury in rice (Oryza sativa L.) grain. Environmental Science and Technology, 44: 4499-4504.

L. Zhang, H. Matsumoto, (2005). Immobilization of aluminum with phosphorus in roots is associated with high aluminum resistance in buckwheat. Plant Physiology, 138(1): 297-303.

879. 